Date of Publication:

30/07/2012

\section{Cunninghamia}

A journal of plant ecology for eastern Australia
The Royal

BotaNIC GARDENS ¿ Domain Trust

ISSN 0727-9620 (print) • ISSN 2200-405X (Online)

\title{
Ephemeral wetlands of the Pilliga Outwash, northwest NSW
}

\author{
Dorothy M. Bell ${ }^{1}$, John T. Hunter ${ }^{2} \&$ Lisa Montgomery $^{3}$ \\ ${ }^{1}$ Botany, School of Environmental and Rural Science, University of New England, Armidale, NSW 2351, \\ ${ }^{2}$ School of Behavioural, Cognitive and Social Sciences, University of New England, Armidale, NSW 2351, \\ ${ }^{3}$ Office of Environment \& Heritage, Baradine, NSW 2396 AUSTRALIA
}

\begin{abstract}
The floristic composition and vegetation partitioning of the ephemeral wetlands of the Pilliga Outwash within the Pilliga National Park and Pilliga State Conservation Area (30 $30^{\prime}$ 'S, $149^{\circ} 22^{\prime}$ E) on the North Western Plains of New South Wales are described. SPOT5 imagery was used to map 340 wetlands across the Pilliga Outwash. A total of 240 plots within 31 wetlands explored composition and species richness in relation to water depth and wetland size. The predominant community described is the species-rich herbfield of shallow basin wetlands, along with the structurally distinct but the less common sedgeland/herbfield of the deeper 'tank' wetlands and a single wetland with a floristically depauperate Diplachne fusca wet grassland. A total of 131 taxa were recorded including three species listed under the NSW Threatened Species Conservation Act (1995): Eriocaulon australasicum, Lepidium monoplocoides and Myriophyllum implicatum. New records for an additional six taxa were recorded for the North Western Plains. 11\% of taxa were exotic in origin.
\end{abstract}

Cunninghamia (2012) 12(3): 181-190

doi: 10.7751/cunninghamia.2012.12.015

\section{Introduction}

Wetland conservation and management requires adequate knowledge of wetland distribution (Kingsford et al. 2004), extent and floristic composition. In Australia impermanent wetlands are far more common and widely distributed than are permanent lakes and swamps (Paijmans et al. 1985) yet in a global review of ephemeral wetlands (Deil 2005), plot-related data were only available in the literature for Western Australia; for the rest of the continent only general classifications of wetland types were available at that time (Pressey \& Adam 1995). To our knowledge, since 2005, information on temporary and ephemeral wetlands has only been collated for some areas of New South Wales (Hunter \& Bell 2007; Bell et al. 2008; Hunter \& Bell 2009). In other areas such as western New South Wales, such information is often only available as part of localized vegetation description (McGann et al. 2001), regional vegetation description (Benson et al. 2006; Benson et al. 2010), or from descriptions of communities establishing from seed banks (James \& Capon 2007; Porter et al. 2007). Wetland covers $5.6 \%$ of New South Wales; of this portion $96 \%$ is in western New South Wales (Kingsford et al. 2004). Kingsford et al. (2004) list six types of spatially derived wetland groups for New South Wales: Freshwater Lakes, Floodplain Wetland, Estuarine Wetland, Saline Lake, Coastal Lagoons and Lakes and Reservoirs. However in the Pilliga Scrub, south west of Narrabri, exist a group of small ephemeral wetlands, that do not conform to these broad wetland types, nor, unsurprisingly, to the broad categories of wetlands described by Keith (2004). The vegetation of these Pilliga wetlands was first described by Benson et al. (2010), who named these wetlands Pilliga 
"tank gilgai" wetland sedgeland rushland, Brigalow Belt South Bioregion (Veg. Comm. ID 416), and considered them to be endangered. Coincidentally this wetland community was also described as a separate vegetation community, Tank Herbfields, by floristic analysis within the Pilliga National Park and Pilliga State Conservation Area (Hunter 2010). These initial descriptions were based on a limited amount of data and observation and a limited knowledge of wetland distribution.

The climate of the Pilliga is dry subtropical with moderately dry winters (Benson et al. 2010) and the majority of wetlands are likely to fill at most once a decade. Large rainfall events in 2010 through to early 2011 repeatedly filled the wetlands and provided an opportunity for investigation, the intention of which was to circumscribe the location, type and extent of these wetlands, to describe their floristic composition and to put them in context with other wetland types within the region.

\section{Methods}

\section{Study area}

The area studied falls within the Brigalow Belt South Bioregion south of the Namoi River Floodplain and forms part of the north western portion of the 500000 ha Pilliga Scrub which occurs between Coonabarabran, Narrabri and Pilliga. Most of the study area comprises outwash sands, loams and clays resulting primarily from the erosion of upland sandstones further to the south (Keith 2004). Benson et al. (2010) described the wetlands as occurring on alkaline sodic grey clay soils with sodic sandy soils in the surrounding Buloke (Allocasuarina luehmannii) woodland. Two ephemeral waterways, Goona Creek and Coghill Creek, cross the study area from east to west.

We chose locations within Pilliga National Park and part of the adjoining Pilliga State Conservation Area, in order to investigate wetlands within an area managed for conservation

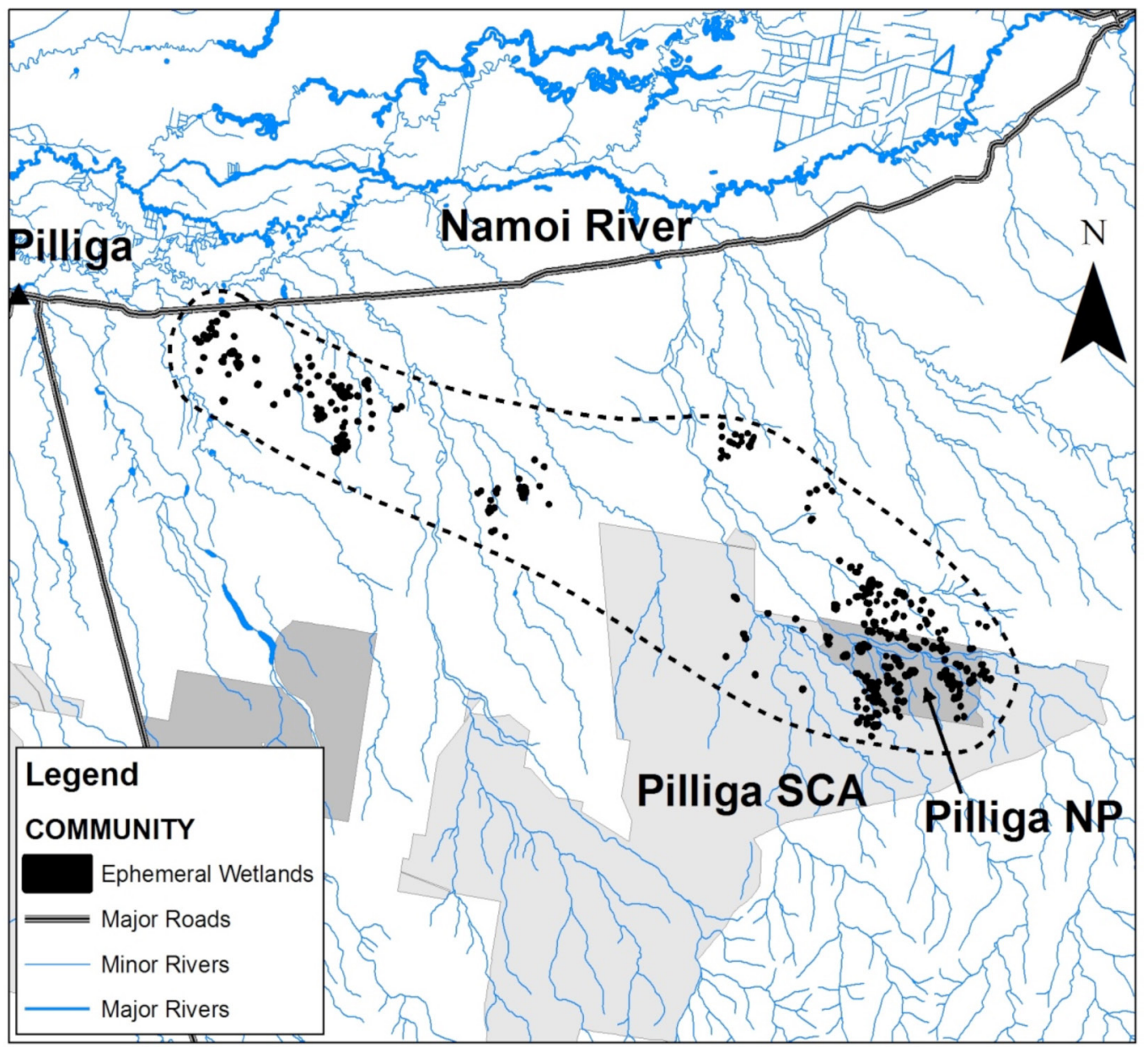

Fig. 1. Distribution of ephemeral wetlands in the Pilliga Outwash. The dotted line indicates the extent of the ephemeral wetlands area; wetlands themselves are shown in black, borders are thickened for visibility. Wetlands occur in Pilliga National Park (Pilliga NP), in the surrounding Pilliga State Conservation Area (Pilliga SCA) and in lands to the north and northwest of these. The area bounded by the dotted line measures approximately $40 \mathrm{~km}$ by $8 \mathrm{~km}$. 
where disturbance is assumed to be more limited. Pilliga State Conservation Area surrounds Pilliga National Park along its eastern, southern and western boundaries (Fig. 1). Pilliga National Park lies approximately $44 \mathrm{~km}$ southwest of Narrabri (30 $30^{\prime} \mathrm{S}, 149^{\circ} 22^{\prime}$ E). Rainfall in 2010 was approximately twice the yearly average with the Bureau of Meteorology recording a total of $1119 \mathrm{~mm}$ in 2010 for Baradine, southwest of Narrabri, on the western edge of the Pilliga $\left(30^{\circ} 36^{\prime} \mathrm{S}, 148^{\circ} 58^{\prime}\right.$ E, elevation $211 \mathrm{~m}$, mean annual rainfall $576 \mathrm{~mm}$ ).

\section{Sampling}

Wetland locations were identified using SPOT5 imagery (Fig. 1). Each location was digitized and mapped with ArcGIS 9.3 and Geo-referenced SPOT5 imagery in order to measure areas of individual wetlands using polygons. Wetland size was verified in the field. Ground truthing of all mapped wetlands within Pilliga National Park and Pilliga State Conservation Area was carried out on quad bikes in the early part of the sampling period, to distinguish depressions capable

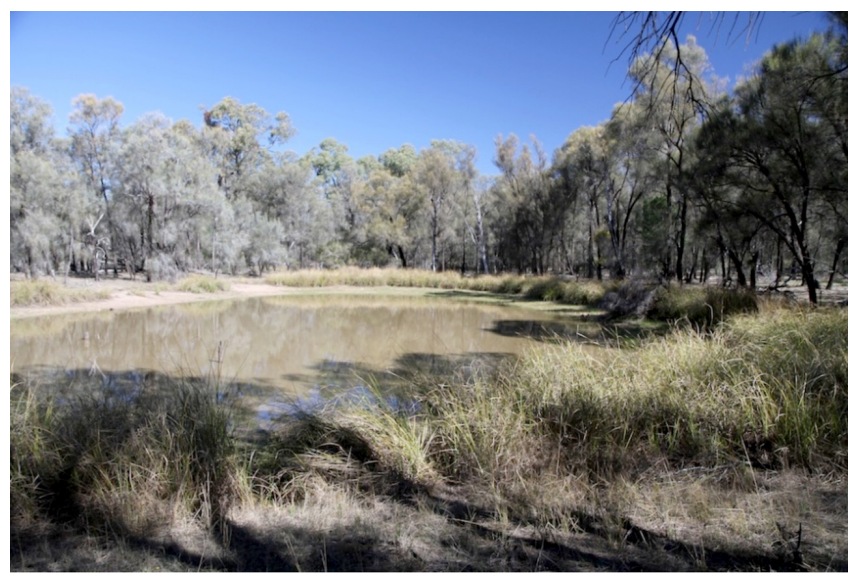

Fig. 2. 'Tank' wetland, Pilliga NP, September 2011 (Wetland 96 West, 30³0'24'S, 149 20'15’E).

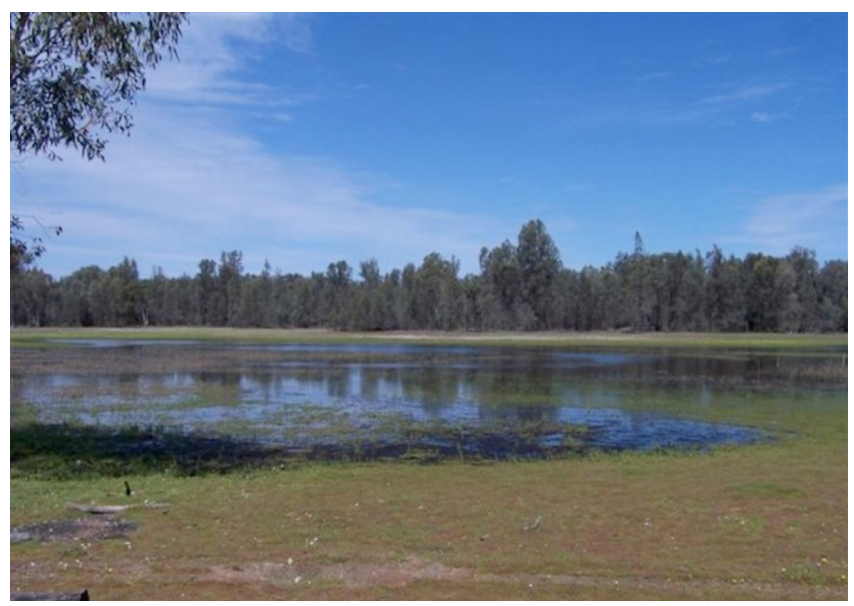

Fig. 3. Shallow basin wetland on Old Coghill Road, Pilliga NP, October 2010 (Wetland 37, 30³0'26”S, 149²2'16”E). of holding water from other bare but sloping areas such as scalds. From the 107 depressions identified as wetlands, 31 wetlands were chosen for sampling; these covered a range of wetland sizes and locations within the reserves.

In spring-summer 2010-2011, in each of the 31 wetlands, up to three transects were placed in random positions across depth gradients from the edge of the surrounding trees, to the deepest parts of the wetland. Each transect was permanently marked with small posts to allow sites to be revisited. The cover abundance of all vascular species and charophytes on a modified Braun-Blanquet (1982) scale (1-6) was assessed in $2 \mathrm{~m} \mathrm{x} 2 \mathrm{~m}\left(4 \mathrm{~m}^{2}\right)$ plots. These plots were placed within visually distinct vegetation bands along each transect ( 2 to 4 per transect; 240 plots in total). Plot water depths and distance from the starting point were also recorded. Conductivity and pH were measured in five wetlands in March 2011.

Appropriate plant specimens were retained for lodging in the N. C. W. Beadle Herbarium, University of New England with duplicates to the National Herbarium of NSW. Nomenclature follows that of PlantNet (2011) except where recent changes have been published elsewhere.

\section{Analyses}

Two data sets were prepared, the first of all plots separately, the second of summed plot data for individual wetlands. Analyses and data exploration were performed using options available in the PATN Analysis Package (Belbin 1995a, b). All species and their cover abundance scores were used and the analysis performed using the Kulczynski association recommended for ecological applications (Belbin 1995a, b) along with flexible UPGMA fusion strategy and the default PATN settings. Community dissimilarity was determined at the 0.85 level.

\section{Results}

340 wetlands were mapped within the broader study area of which 107 occurred within the Pilliga National Park and State Conservation Area (Fig. 1). The total area covered by these wetlands is approximately 121 ha with $92 \%$ of wetlands being under 1 ha in size. Wetlands occurred across a $40 \mathrm{~km}$ by $8 \mathrm{~km}$ ellipse from the Pilliga National Park northwest to near the township of Pilliga (Fig. 1). The wetlands occurred within a mosaic of woodlands and shrublands largely dominated by Allocasuarina luehmanii, Eucalyptus chloroclada, Eucalyptus pilligaensis, Eucalyptus sideroxylon and Melaleuca densispicata (Benson et al. 2010; Hunter 2010).

The wetlands fall into two distinct morphological types; 'tank', and shallow basin wetlands. 'Tank' wetlands are roughly circular to irregularly oblong basins with a distinct lip to $30 \mathrm{~cm}$ high, on yellowish soils with higher clay content, often in Melaleuca densispicata tall shrubland 
where extensive scalds are common (Fig. 2). "Tank" wetlands usually contain turbid, more permanent water than that of shallow basin wetlands, and can hold water for two to three months. Shallow basin wetlands are on yellowish soils of higher sand content especially at margins. There is a sharp boundary at the woodland edge and shallow basin wetlands are more commonly surrounded by Allocasuarina luehmannii (Fig. 3). Water is often, but not always, clear and the smallest wetlands dry in a matter of weeks.

A total of 131 vascular plant taxa in 49 families and 97 genera were recorded in plots and from opportunistic sightings. Four charophyte taxa in the genera Chara and Nitella were recorded. Families with the most taxa overall were Asteraceae (21 species), Cyperaceae (19 species) and Poaceae (12 species). The richest genera were Cyperus (8 species), Juncus (6 species) and Myriophyllum (4 species).

\section{Vegetation Assemblages}

Three communities were defined in the whole wetland analysis (Figure 4):

\section{Community 1: Cyperus gunnii subsp. gunnii-Nymphoides crenata sedgeland/herbfield.}

Wetland type: 'Tank' wetland. Turbid open water with a usually continuous 1-2 m wide margin dominated by the tall sedge Cyperus gunnii subsp. gunnii (height to $1.5 \mathrm{~m}$ ), occasionally with floatingleaved Nymphoides crenata populations in deepest part of basin. As water recedes, a low $(0.1-0.2 \mathrm{~m})$ herbfield of ruderal species appears on damp mud.

Terrestrial and semi terrestrial: Eragrostis elongata, Hypericum gramineum, Commelina cyanea, Chloris truncata, Alternanthera denticulata, Sporobolus caroli, Fimbristylis dichotoma, Eragrostis parviflora, Cyperus gracilis, Dichelachne crinita, Dianella revoluta subsp. revoluta.

Ruderals and mud flat colonisers: Glinus oppositifolia, Epaltes australis, Eleocharis pusilla, Lipocarpha microcephala, Cyperus difformis, Chenopodium pumilio, Portulaca filifolia, Fuirena incrassata.

Emergents: Cyperus gunnii subsp. gunnii, Myriophyllum simulans, Juncus subsecundus, Eleocharis macbarroni, Juncus psammophilus, Philydrum lanuginosum, Eleocharis plana, Mitrasacme paludosa, Diplachne fusca, Cyperus betchei subsp betchei.

Floating-leaved: Nymphoides crenata.

Submerged: None.

Exotics: Bidens pilosa, Gomphrena celosioides, Spergularia rubra, Xanthium occidentale.

Variability: Sometimes Cyperus gunnii subsp. gunnii margin not intact, margins not so distinctly lipped. Generally less species-rich (9 to 20 species per wetland) than Community 2 .

Community 2: Eleocharis pusilla - Myriophyllum simulans - Nymphoides crenata - Marsilea hirsuta Pseudoraphis spinescens herbfield/sedgeland with an ephemeral component dominated by Goodenia gracilis Centipeda minima subsp. minima - Gratiola pedunculata - Alternanthera denticulata.

Wetland type: Shallow basin wetlands.

Terrestrial and semi terrestrial: Eragrostis elongata, Hypericum gramineum s.lat.,Wahlenbergia tumidifructa, Wahlenbergia gracilis, Bulbine semibarbata, Commelina cyanea, Ophioglossum lusitanicum, Fimbristylis dichotoma, Walwhalleya subxerophylla, Chamaesyce drummondii, Murdannia graminea, Rumex tenax, Plantago turrifera, Lepidium monoplocoides, Portulaca oleracea, Chloris truncata.

Ruderals and mud flat colonisers: Goodenia gracilis, Centipeda minima subsp. minima, Epaltes australis, Gratiola pedunculata, Alternanthera denticulata, Myriophyllum implicatum, Calandrinia pumila, Peplidium foecundum, Calandrinia eremaea, Brachyscome goniocarpa, Crassula sieberiana, Ranunculus sessiliflorus var.

Cyperus gunnii subsp. gunnii -

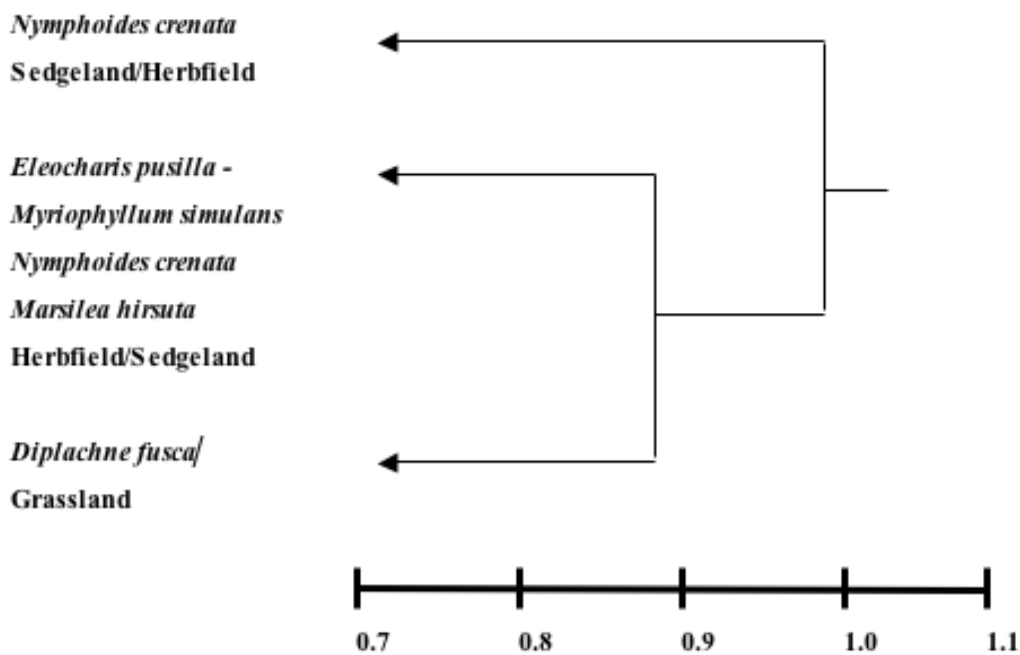

Fig. 4. Summary dendrogram of 31 ephemeral wetlands surveyed within Pilliga NP and Pilliga State Conservation Area using Kulczynski association and flexible UPGMA fusion strategy. Communities have been defined at a dissimilarity level of c. 0.85 . 
pilulifer, Carex inversa, Cyperus flaccidus, Elatine gratioloides, Cyperus squarrosus, Centrolepis strigosa subsp. strigosa, Centipeda thespidioides, Eriocaulon australasicum, Lipocarpha microcephala, Drosera indica, Isolepis hookeriana, Myriocephalus pluriflorus, Centrolepis eremica, Helichrysum luteoalbum, Lachnagrostis filiformis, Cyperus difformis, Callitriche sonderi, Triglochin calcitrapa, Juncus bufonius, Portulaca filifolia, Fuirena incrassata, Calotis hispidula, Senecio glossanthus, Plantago turrifera, Myriocephalus rhizocephalus, Myosurus australis, Triptilodiscus pygmaeus, Polygonum plebeium, Cyperus sanguinolentus, Lythrum hyssopifolia, Euchiton sphaericus, Brachysome multifida var. multifida, Portulaca bicolor var. rosea, Drosera peltata, Drosera burmanni.

Emergents: Eleocharis pusilla, Myriophyllum simulans, Cyperus gunnii subsp. gunnii, Glossostigma diandrum, Marsilea hirsuta, Pseudoraphis spinescens, Isoetes muelleri, Hydrocotyle tripartita, Juncus subsecundus, Mimulus gracilis, Mitrasacme paludosa, Isotoma fluviatilis subsp. borealis, Eleocharis plana, Marsilea costulifera, Myriophyllum verrucosum, Diplachne fusca, Cynodon dactylon, Eleocharis pallens, Utricularia dichotoma, Schoenus apogon, Philydrum lanuginosum, Rorippa laciniata, Juncus psammophilus, Juncus aridicola, Juncus flavidus, Eryngium paludosum, Eleocharis macbarronii, Amphibromus nervosus, Cyperus rigidellus, Cyperus gymnocaulos, Cyperus betchei subsp. betchei, Juncus ochrocoleus.

Floating-leaved: Nymphoides crenata, Nymphoides geminata, Potamogeton sulcatus, Ottelia ovalifolia subsp. ovalifolia, Damasonium minus, Triglochin multifructa.

Submerged: Najas tenuifolia, Vallisneria australis, Chara fibrosa, Chara sp., Nitella sonderi, Nitella sp.

Exotics: Soliva anthemifolia, Schoenoplectus erectus, Sisyrinchium sp. A, Sagina apetala, Conyza bonariensis, Cuscuta campestris, Gamochaeta coarctata, Spergularia rubra, Veronica peregrina, Anagallis arvensis, Gomphrena celosioides, Xanthium occidentale, Vulpia bromoides, Sonchus oleraceus, Gamochaeta calviceps, Centaurea melitensis.

Variability: This community occurred in wetlands varying greatly in both size $(<0.05$ to $3.6 \mathrm{ha})$ and depth $(0$ to $>70 \mathrm{~cm}$, although the lower limit is misleading since a few very shallow wetlands were dry when sampled). Species richness per wetland was also highly variable ( 8 to 42 species) and appeared to bear no relationship to either wetland size or wetland depth. Some quite small wetlands were species-rich, others species-poor; the most species-rich wetland was relatively large but other large wetlands were species-poor.

\section{Community 3: Diplachne fusca grassland.}

Wetland type: Sampled at a single site. Species-poor, very shallow basin wetland, sandy sloping margins.

Terrestrial and semi terrestrial: Lepidium monoplocoides.

Ruderals and mud flat colonisers: Calandrinia eremaea, Epaltes australis.

Emergents: Diplachne fusca, Cynodon dactylon.

Floating-leaved: None.

Submerged: None.

Exotics: Spergularia rubra.

Variability: Not known.

\section{Species richness}

Plot species richness across wetland depth gradients (as distinct from richness in whole wetlands) was highly variable. Plots in the deepest parts of the wetlands generally had lower species richness $\left(1-5 / 4 \mathrm{~m}^{2}\right)$ but variability in plots on damp soil was very high $\left(3-27 / 4 \mathrm{~m}^{2}\right)$ and did not appear to vary with wetland size. Whole wetland richness varied from eight in one of the smallest wetlands to 54 in one of the largest.

The water in wetlands sampled in March 2011 was slightly acid to slightly alkaline ( $\mathrm{pH} 6.4$ to 7.9 ). Water quality in partially dry wetlands was good with conductivity ranging from $181 \mathrm{uS} / \mathrm{cm}$ to $510 \mathrm{uS} / \mathrm{cm}$.

\section{Discussion}

Two distinct communities relating to basin geomorphology (and an additional depauperate single wetland community) are described for the wet phase of these wetlands. Community 2 (Eleocharis pusilla - Myriophyllum simulans - Nymphoides crenata - Marsilea hirsuta - Pseudoraphis spinescens herbfield/sedgeland) occurs in broad gently sloping basins. As water recedes from the edges of this basin, the species-rich ephemeral component (Eleocharis pusilla, Goodenia gracilis, Centipeda minima subsp. minima, Epaltes australis, Isoetes muelleri) is established towards the margins and in central deeper areas, a few true aquatics (submerged, floating-leaved and emergents e.g. Najas tenuifolia, Potamogeton sulcatus and Triglochin procera) are found especially in clear water (Fig. 5). In some wetlands the deeper water has a monoculture of Myriophyllum simulans with the edges a monoculture of Eleocharis pusilla with a smattering of other species. Species richness per plot is much reduced in the dry phase; in one of the largest wetlands, the wet phase had more than twice the species richness of the dry phase (Benson et al. 2010; Hunter 2010). There are also some compositional differences between wet and dry phases (see Appendix). These ephemeral wetlands are more species rich than the semi-permanent upland wetlands of the Northern Tablelands (Bell et al. 2008). In this sampling season 72 species occurred in the four largest Pilliga Outwash wetlands compared to 47 species for one sampling season in five upland wetlands (D. Bell, unpublished data).

\section{Morphology}

The local name for these wetlands is 'gilgai', 'tank gilgai' or simply 'tanks'. Gilgais are soil surface undulations in desert landscapes that result from differential movements of clay soil blocks (Hallsworth et al. 1955; Beadle 1981). The distinctive lattice gilgai patterns on the grey cracking clays under Brigalow to the north and northwest of Pilliga National Park and Pilliga State Conservation Area can clearly be distinguished on SPOT5 imagery from the less patterned and more random ephemeral wetlands of the Pilliga Outwash; it is unlikely that Pilliga Outwash wetlands are formed through gilgai processes (Jim Charley pers. comm.). The geology of Pilliga National Park is sand plain, with sand predominant, gravel, and clay; the geology 
northwest is channel and floodplain alluvium (Atlas of NSW 2011). Outwash wetlands are thought to be depressions originating from former billabongs or ponds left over from ancient drainage lines, with the 'tank' depressions possibly from more recent streams and their associated wetlands (Jim Charley pers. comm.). Similar ponds occur sporadically today along Coghill Creek.

\section{Variability}

Multiple levels of variability in the sampling data relate to the timing of rainfall events, sampling times, salinity and possibly to metapopulation dynamics. There is a degree of unpredictability in whole wetland species richness not apparently related to wetland size. There was no obvious explanation for some small wetlands (and some large) having many species and others not. Some wetlands may have more sodic soils limiting them to more salt tolerant species or the discrepancies may be due solely to chance. Opportunistic colonization or extinction theoretically could result in smaller population sizes, since filling events are highly stochastic and localized. Some wetlands were no doubt sampled at an early establishment phase since filling; others at a later stage when herbfields were well established. These are common methodological issues for sampling in aseasonal ephemeral wetlands. The isolation in space of some of the wetland populations may also limit dispersal of some species and result in their limitation to certain wetlands. Further exploration of the elements of this variability could involve further sampling in both wet and dry phases and soil and water testing.

\section{Wetting/drying regime}

Details of the depth, frequency, duration, extent and variability of filling of these wetlands are as yet unknown, and likely to be unpredictably stochastic. We presume that the wetlands only fill from overland flow after extraordinary rainfall events or series of events, but partially fill or remain damp for some time after any reasonably large rainfall event. Seed banks of ruderal species are no doubt replenished as a result of these smaller events but true aquatics (deep water floating-leaved, submerged and emergents) rely on longterm persistence of seeds, tubers (Triglochin multifructa) or rhizomes (Juncus, Cyperus gunnii subsp. gunnii) in the soil.

Rainfall is not only sporadic but usually highly localized so that some wetlands fill while others may remain dry. That fraction that fills allow species to complete life cycles and contribute to persistence of these wetland communities in the landscape.

\section{Similarities to other wetlands}

These small but discrete lentic wetlands are found only within that relatively small area of the Pilliga Scrub towards the northwestern edge of the Pilliga Outwash and are generally associated with closely patterned ephemeral creeks and waterways (Figure 1). In the area searched on SPOT 5 imagery (between Pilliga township, the Namoi River and Narrabri in the north and the Pilliga sandstone escarpment in the south), the only other lentic wetlands detected were occasional dams, the much larger Yarrie Lake and the distinctly patterned lattice gilgae on heavy clays. Shallow ephemeral wetlands with sporadic wetting and drying cycles are however not unique to the Pilliga. Although mostly undescribed (but see McGann et al. 2001), ephemeral wetlands are known to occur in other semiarid to arid parts of NSW (see Porter et al. 2007). But we are unaware of any that are numerous enough to form aggregations in such a relatively small area and on such distinctive geomorphology.

\section{Growth form types}

Growth form types encountered in these wetlands are similar to those of ephemeral wetlands worldwide: dwarf annuals or short-lived species such as Eleocharis pusilla, Crassula sieberiana, Eriocaulon australasicum, Centrolepis eremica,

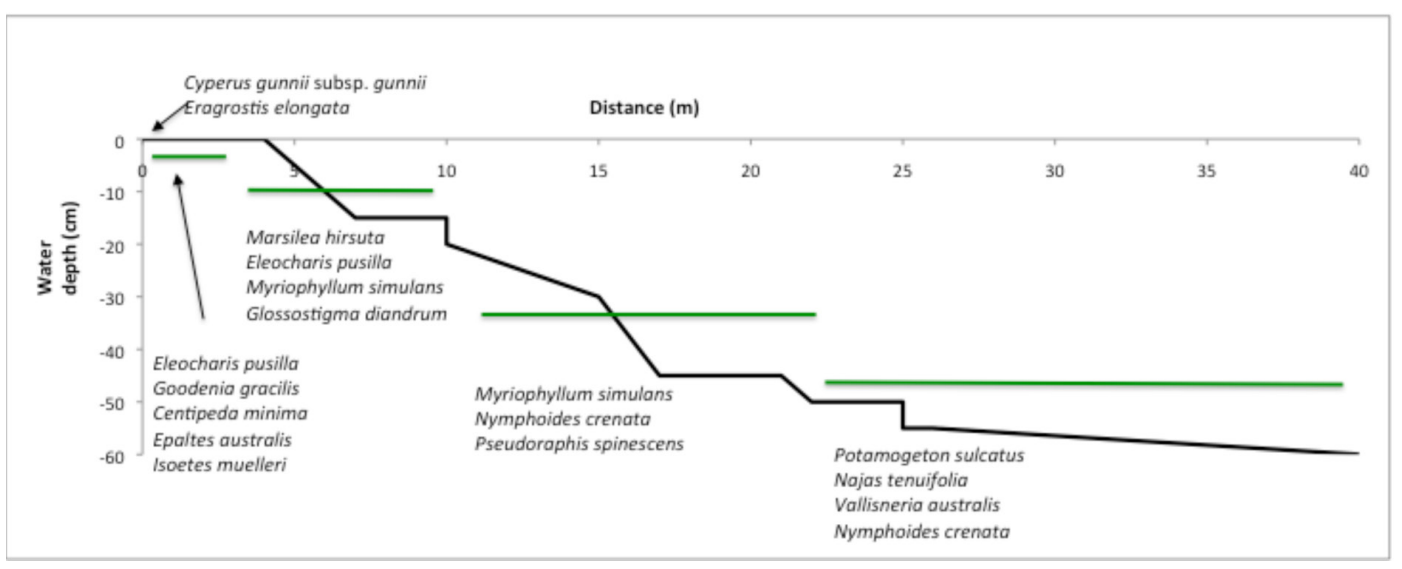

Fig. 5. Typical Community 2 changes in dominant species along a water depth gradient in two large shallow basin wetlands. The black line indicates changes in water depth; the green line distributional changes in dominant species with depth and distance from wetland margins. 
Callitriche sonderi, Ranunculus sessiliflorus and geophytic perennials (species with persistent bases) such as Isoetes muelleri and Ophioglossum lusitanicum (Deil 2005). Many more species are ruderal or short-lived rather than perennial and of those species establishing on damp soil few are clonal (e.g. Eleocharis pusilla), in contrast to the strictly clonal aquatic species of the deeper water. Not all species in the ephemeral herbfield component are wetland specialists but belong to those taxa encountered on damp soils in many other situations such as in riparian areas and drainage depressions (e.g. Epaltes australis).

\section{Former land-use}

The wetlands, especially the 'tank' wetlands, appear to have been of use as a bare (i.e. tree-free) area by pastoralists. The remains of a small stockyard was seen in one wetland; others have remnants of fencing around them and were apparently used with a rough one-way gate to trap and herd cattle. One or two others provided an open area for cutting and stacking sleepers.

\section{Species significance}

Three species currently listed on the NSW Threatened Species Conservation Act 1995 were found within the wetlands and six others were considered regionally significant. The small annual herb Eriocaulon australasicum (Family Eriocaulaceae) was occasional to common in plots in four of the wetlands surveyed; this species is listed as Endangered, both federally (EPBC Act) and statewide (TSC Act), and in ROTAP (3V). There was a very early collection along the Murray River in New South Wales (OE\&H 2011a; PlantNet 2011). Eriocaulon australasicum is known from a few populations in Victoria and adjoining South Australia.

The annual herb Lepidium monoplocoides (Family Brassicaceae), found scattered at wetland margins, is listed as

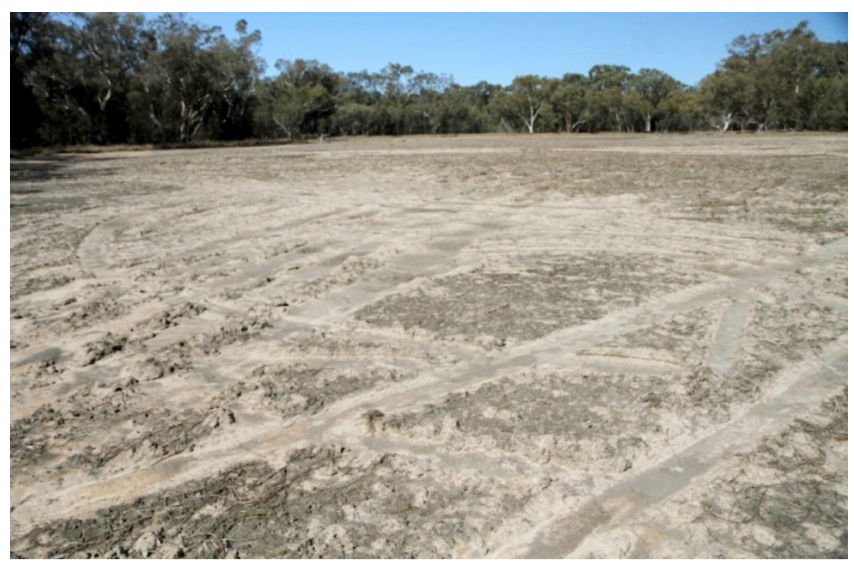

Fig. 6. Soil disturbance by recreational vehicles in a shallow basin wetland, Pilliga NP, September 2011 (Wetland 98, 30³0'15"S, $\left.149^{\circ} 20^{\prime} 27^{\prime \prime} \mathrm{E}\right)$.
Endangered both federally (EPBC Act) and statewide (TSC Act) and in ROTAP (3ECi) and is known from semi-arid regions of New South Wales, Victoria and possibly South Australia.

Myriophyllum implicatum (Family Haloragaceae), a strictly dioecious creeping herb (Orchard 1985) that forms discrete mats on damp mud and can tolerate shallow water, was found in four localized shallow basin wetlands, in one of which it was the dominant species in an extensive band near the water's edge. Myriophyllum implicatum is usually confined to coastal areas in south-eastern Queensland with an undated record from the Hastings River in north-eastern New South Wales (OE\&H 2011b) and was considered extinct in New South Wales until collected in 2008 by John Benson during surveys in the Pilliga Region (Benson et al. 2010; PlantNet 2011).

Six species are considered regionally significant since they are disjunct or thought to be at or near their geographic limits. These taxa are: Centrolepis eremica, Drosera burmanni, Hydrocotyle tripartita, Isoetes muelleri, Peplidium foecundum and Philydrum lanuginosum. Of interest also are the Nymphoides geminata populations. Nymphoides geminata is usually homostylous but populations in the Pilliga Outwash are consistently heterostylous.

\section{Soil disturbance}

Soil disturbance risks both disruption of the seed bank by deeper burial of seeds and encouragement of weedy species. Minor to extensive digging by wild pigs was seen in almost all wetlands in 2010; pig wallows in deep holes were also seen in September 2011. In addition, the soil surface of the more accessible wetlands shows evidence of deep wheel tracks of recreational vehicles (Fig. 6). Trampling and grazing by stray cattle, feral goats and horses are also potential threats to soil stability.

A plume of deposited soil from the erosion of a gully and scald close to the northern boundary has the potential to enlarge and to ultimately fill one of the 'tank' wetlands. Road construction in or near wetlands is also a potential threat.

\section{Road construction and hydrological change}

A road has been constructed through the middle of one of the mapped shallow basin wetlands with associated roadside drains and additional drains elsewhere in the basin. During a drought in late 2010 this drained wetland was described as an ephemeral herbfield but with almost none of the ephemeral wetland flora described for Community 2 (Hunter 2010). Hunter (2010) described this community as a derived herbfield dominated by Tripogon loliiformis and Enteropogon acicularis, floristically distinct from the Bulbine semibarbata - Calandrinia eremaea herbfield in an intact wetland sampled during the same survey. Some wetlands on private property to the north and northwest appear to have been made more permanent by impoundment. 
Weeds

Only $11 \%$ of taxa sampled during this survey were exotic. Of these the small sedge Schoenoplectus erectus is known to cause problems elsewhere (Benson et al. 2010), but is not as yet a common component of these wetland communities.

\section{Conservation}

We recommend that these ephemeral wetland communities be considered endangered in New South Wales. Benson et al. (2010) states that they are inadequately protected and gives them the threat category Endangered (E/3c threat criteria 2,4). These wetlands are relatively rare and localized in the Pilliga Outwash landscape and are morphologically distinct from and should not be confused with the more common lattice gilgai depressions on grey cracking clays under Brigalow on lands to the north and northwest. Only one third of the mapped wetlands occur in reserves. Further addition of lands to reserves or voluntary conservation agreements would be beneficial to conservation, as well as population studies of threatened species and monitoring of weed invasion. Protection from recreational vehicles, pig control and sedimentation is urgently required. Revisiting and sampling the permanently marked sites in both wet and dry phases would provide additional knowledge on the vegetation dynamics of these communities.

\section{Acknowledgements}

The NSW Office for Environment and Heritage at Baradine is thanked for providing vehicles and staff to assist the survey. Sincere thanks are also due to Shane Edmonstone who assisted the third author in quad bike ground-truthing of wetlands, and to Kate Smiley, Daniel Bailey, and Jon Burne for assistance with fieldwork. Ian Telford of the N. C. W. Beadle Herbarium, University of New England and John Hosking are thanked for assistance with species nomenclature and identification.

\section{References}

Atlas of NSW (2011). Accessed 13 ${ }^{\text {th }}$ October 2011.

(http://atlas.nsw.gov.au/public/nsw/home/map/vegetation.html)

Beadle, N.C.W. (1981) The vegetation of Australia. Cambridge University Press, Melbourne.

Belbin, L. (2004) PATN Pattern analysis package. (CSIRO Division of Wildlife Ecology: Canberra).

Belbin, L. (1995a) Users guide: PATN pattern analysis package. (Division of Wildlife \& Ecology CSIRO: Canberra.

Belbin, L. (1995b) Technical reference: PATN pattern analysis package. (Division of Wildlife \& Ecology CSIRO: Canberra.

Bell, D.M., Hunter, J.T. \& Haworth, R.J. (2008) Montane lakes (lagoons) of the New England Tablelands Bioregion. Cunninghamia 10: 475-492.
Benson, J.B., Allen, C., Togher, C. \& Lemmon, J. (2006) New South Wales Vegetation classification and Assessment: Part 1 Plant communities of the NSW Western Plains. Cunninghamia 9: 383-451.

Benson, J.B., Richards, P.G., Waller, S. \& Allen, C.B. (2010) New South Wales Vegetation classification and Assessment: Part 3 Plant communities of the NSW Brigalow Belt South, Nandewar and west New England Bioregions and update of NSW Western Plains and South-western Slopes plant communities, Version 3 of the NSWVCA database. Cunninghamia 11: 457-579.

Braun-Blanquet, J. (1982) Plant sociology: the study of plant communities. (McGraw Hill: New York).

Deil, U. (2005) A review on habitats, plant traits and vegetation of ephemeral wetlands - a global perspective. Phytocoenologia 35: 533-705.

Hallsworth, E.G., Robertson, G.K. \& Gibbons, F.R. (1955) Studies in pedogenesis in New South Wales: VII The gilgai soils. Journal of Soil Science 6: 1-31.

Hunter, J.T. (2010) Vegetation and floristics of Cubbo, Etoo \& Dewson's Lease sections of the Pilliga SCA, Pilliga NP and Pilliga West SCA. Unpublished report to the Department of Environment, Climate Change and Water.

Hunter, J.T. \& Bell, D.M. (2007) Vegetation of montane bogs in eastern flowing catchments of northern New England, New South Wales. Cunninghamia 10: 77-92.

Hunter, J.T. \& Bell, D.M. (2009) The Carex fen vegetation of northern New South Wales. Cunninghamia 11: 49-64.

James, C.S. \& Capon, S.J. (2007) Spatial variability of the soil seed bank in a heterogeneous ephemeral wetland system in semiarid Australia. Plant Ecology 190: 205-217.

Keith D.A. (2004) Ocean shores to desert dunes: the native vegetation of New South Wales and the ACT. Department of Environment and Conservation: Hurstville.

Kingsford, R.T., Brandis, K., Thomas, P., Crighton, P., Knowles, E. \& Gale, E. (2004) Classifying landform at broad spatial scales: the distribution and conservation of wetlands in New South Wales, Australia. Marine and Freshwater Research 55: 17-31.

McGann, T.D., Kingswood, R. \& Bell, D. (2001) Vegetation of Narran Lake Nature Reserve, North Western Plains, New South Wales. Cunninghamia 7: 43-63.

Office of Environment \&Heritage NSW (OEH) (2011a) Eriocaulon australasicum (a herb) endangered species listing. Accessed $15^{\text {th }}$ September 2011. (http://www.environment.nsw.gov.au/ determinations/EriocaulonAustralasicumEndSpListing.htm)

OE\&H (2011b) Myriophyllum implicatum - critically endangered species listing. Accessed $15^{\text {th }}$ September 2011. (http://www.environment.nsw.gov.au/determinations/ myriophyllumimplicatumFD.htm)

Orchard, A.E. (1985) Myriophyllum (Haloragaceae) in Australasia. II. The Australian Species, Brunonia 8,173-291

Paijmans, K., Galloway, R.W., Faith, D.P., Fleming, P.M., Haantjens, H.A., Heyligers, P.C., Kalma, J.D. \& Loffler, E. (1985) Aspects of Australian wetlands.CSIRO Division, Water \& Land Resources Technical Paper No. 44.

PlantNet (2011) The plant information network system of the Royal Botanic Gardens and Domain Trust Version 2.0. Accessed 15 ${ }^{\text {th }}$ September 2011.(http://plantnet.rbgsyd.nsw.gov.au/)

Porter, J.L., Kingsford, R.T., Brock, M.A. (2007) Seed banks in arid wetlands with contrasting flooding, salinity and turbidity regimes. Plant Ecology 188: 215-234.

Pressey, R.1. \& Adam, P. (1995) A review of wetland inventory and classification in Australia. Vegetatio: 118: 81-101.

Manuscript accepted 2 April 2012 
Appendix 1. Vascular species and charophytes of Pilliga Outwash ephemeral wetlands. Community 1 is sedgeland/herbfield of 'tank' wetlands; 2: herbfield/sedgeland with an ephemeral component in shallow basin wetlands; 3. Diplachne fusca grassland. Exotic taxa are prefixed with an asterisk. Small letters indicate species named in other surveys or recorded opportunistically: a: Benson (2010), b: Hunter (2010), o: opportunistic.

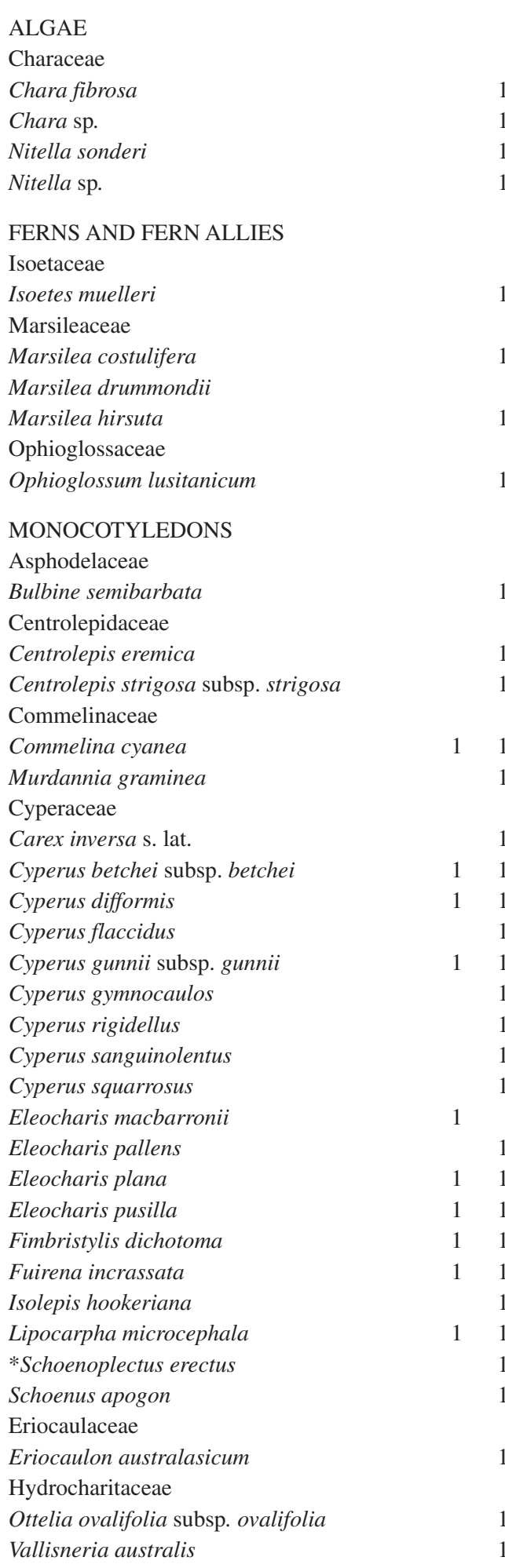

Iridaceae

*Sisyrinchium sp. A

Juncaceae

Juncus aridicola 1

Juncus bufonius 1

Juncus continuus

Juncus flavidus

Juncus ochrocoleus

Juncus psammophilus

Juncus subsecundus

Juncaginaceae

Triglochin calcitrapa

Triglochin multifructa

Najadaceae

Najas tenuifolia

Philydraceae

Philydrum lanuginosum $\quad 1 \quad 1$

Phormiaceae

Dianella revoluta subsp. revoluta

Poaceae

Amphibromus nervosus

Chloris truncata

Cynodon dactylon

Dichelachne micrantha

Diplachne fusca

Eragrostis elongata

Eragrostis parviflora

Eragrostis speciosa

Lachnagrostis filiformis

Panicum decompositum

Pseudoraphis spinescens

Sporobolus caroli

*Vulpia bromoides

Walwhalleya subxerophila

Potamogetonaceae

Potamogeton sulcatus

DICOTYLEDONS

Aizoaceae

Glinus oppositifolius

Alismataceae

Damasonium minus

Amaranthaceae

Alternanthera denticulata

* Gomphrena celosioides

Apiaceae

Eryngium paludosum

Hydrocotyle tripartita

Asteraceae

*Bidens pilosa

1

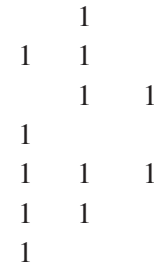

Brachyscome ciliaris var. subintegrifolia

Brachyscome goniocarpa

Brachyscome heterodonta o

a

1

1

a

o

1

1

1

1

1

11

11

1

1

1

1 
Brachysome multifida var. multifida

Brachyscome nodosa

Calotis hispidula

Calotis sp.

*Centaurea melitensis

Centipeda cunninghamia

Centipeda minima subsp. minima

Centipeda thespidioides

*Conyza bonariensis

Epaltes australis

Euchiton sphaericus

* Gamochaeta calviceps

* Gamochaeta coarctata

Helichrysum luteoalbum

Lemooria burkittii

Myriocephalus pluriflorus

Myriocephalus rhizocephalus

Senecio glossanthus

* Soliva anthemifolia

* Sonchus oleraceus

Triptilodiscus pygmaeus

*Xanthium occidentale

Brassicaceae

Lepidium monoplocoides

Rorippa laciniata

Callitrichaceae

Callitriche sonderi

Campanulaceae

Wahlenbergia gracilenta

Wahlenbergia gracilis

Wahlenbergia tumidifructa

Caryophyllaceae

* Sagina apetala

* Spergularia rubra

Casuarinaceae

Allocasuarina luehmannii

Chenopodiaceae

Chenopodium pumilio

Dysphania glomulifera subsp. glomulifera

Clusiaceae

Hypericum gramineum s.lat.

Convolvulaceae

*Cuscuta campestris

Crassulaceae

Crassula sieberiana

Droseraceae

Drosera burmannii

Drosera indica

Drosera peltata

Elatinaceae

Elatine gratioloides

Euphorbiaceae

Chamaesyce drummondii

Gentianaceae

*Centaurium tenuiflorum
Goodeniaceae

Goodenia gracilis

Goodenia sp.

Haloragaceae

Myriophyllum implicatum

b

Myriophyllum simulans

Myriophyllum striatum

a

Myriophyllum verrucosum

Lentibulariaceae

Utricularia dichotoma

Lobeliaceae

Isotoma fluviatilis subsp. borealis

Loganiaceae

Mitrasacme paludosa

Lythraceae

Lythrum hyssopifolia

Menyanthaceae

Nymphoides crenata

Nymphoides geminata

Myrtaceae

Eucalyptus chloroclada

Plantaginaceae

Plantago turrifera

1
1

Polygonaceae

Polygonum plebeium

Rumex tenax

Portulacaceae

b

Calandrinia eremaea

1

Calandrinia pumila

Portulaca bicolor var. rosea

Portulaca filifolia

Portulaca oleracea

Primulaceae

*Anagallis arvensis

Ranunculaceae

Myosurus minimus var. australis $\quad 1$

Ranunculus sessiliflorus var. pilulifer $\quad 1$

Scrophulariaceae

o

Glossostigma diandrum

Gratiola pedunculata

Mimulus gracilis

Peplidium foecundum

*Veronica peregrina
11

1

11

1

1

1

1

1

11

1

1

1

1

\section{1}

1

1

1

1

1 